\title{
Stres na delovnem mestu slovenskega menedžerja
}

\author{
Anja Puntar \\ Univerza na Primorskem, Fakulteta za management, Cankarjeva 5, 6000 Koper, Slovenija \\ anja.puntar@gmail.com \\ Mirko Markič* \\ Univerza na Primorskem, Fakulteta za management, Cankarjeva 5, 6000 Koper, Slovenija \\ mirko.markic@fm-kp.si
}

\section{Povzetek:}

Raziskovalno vprašanje (RV): Kakšna je raven dojemanja stresa med slovenskimi vršnimi, srednjimi in spodnjimi menedžerji v Republiki Sloveniji?

Namen: Namen članka je bil opraviti sistematični pregled strokovne literature na temo vzrokov, dejavnikov in posledic stresa na različnih ravneh organiziranosti menedžerjev v RS od leta 20052019.

Metoda: Metoda za analizo dokumentov je bil sistematičen način zmanjševanja virov in kvantitativne analize njihovih značilnosti (s pomočjo Prizma diagrama).

Rezultati: Kot zelo do izjemno stresno je njihovo delo v povprečju ocenilo 39,6 odstotka, kot srednje stresno 37,3 odstotka, kot malo stresno 15,2 odstotka in kot ne stresno 7,9 odstotka anketiranih menedžerjev.

Družba: Raziskava obravnava zaznavanje stresa menedžerjev kot priložnosti za iskanje potencialnih razrešitev za odpravo oziroma omejitev dejavnikov, ki nanj vplivajo. Ti negativno vplivajo tako na uspešnost podjetja ali druge ustanove, zdravstveni in socialni sistem kot tudi na trajnostni razvoj družbe.

Originalnost: $\mathrm{S}$ sistematičnim pregledom opravljenih raziskav o zaznavanju stresa med slovenskim vršnimi, srednjimi in spodnjim menedžerji smo prišli do novih spoznanj, ki v dosedanjih raziskavah še niso bile ugotovljene.

Omejitve/nadaljnje raziskovanje: Izidov iz raziskave o ravni dojemanja stresa med slovenskimi, vršnimi, srednjimi in spodnjimi menedžerji ni mogoče posplošiti na celoto populacijo menedžerjev, prav tako pa jih ni možno posplošiti na standardne dejavnosti in velikost gospodarske družbe. Podali smo predloge za nadaljnje raziskovanje stresa med slovenskimi menedžerji.

Ključne besede: delovno mesto, menedžment, menedžerji, raziskave, Slovenija, stres.

\section{Uvod}

Obravnavanje stresa na delovnem mestu je prisotno že dlje časa in se nanaša na vse skupine zaposlenih (»od čistilke do direktorja«). Delovno okolje in delovno mesto se nenehno spreminja in s tem povzroča dejavnike stresa, ki jih je potrebno spremljati in se jim 
prilagajati. Lastniki oz. delničarji v preteklosti niso namenjali veliko pozornosti dobremu počutju menedžerjem in njihovim sodelavcev v delovnem okolju. Družbena in gospodarska zgodovina nam pokaže, da je bilo potrebno veliko časa, da se je razvilo delovno razmerje, kjer je »blaginja službe« prepoznana kot pristojnost in odgovornost lastnikov organizacije. Z gospodarskim razvojem in večjimi možnosti za delo in napredovanje, so dejavniki stresa postali neizogiben spremljevalec našega življenja, ki se z leti povečujejo in s seboj prinašajo fizične, fizikalne, kemijsko-biološke, organizacijske in psihosocialne težave, ki vodijo v poškodbe ter zdravstvene okvare. Pretirani pritiski na delovnem mestu menedžerjev ne ogrožajo le zdravja zaposlenih sodelavcev, ampak vplivajo tudi na »zdravje« organizacije oz. njeno uspešnost. Odsotni ali bolni zaposleni menedžerji ne morejo prinašati maksimalne dodane vrednosti organizaciji, zato zmanjšujejo njeno produktivnost in konkurenčnost.

\section{Teoretična izhodišča}

Beseda stres izvira iz latinščine in je bila prvič uporabljena v 17. stoletju. Pomenila je pritisk, stiske in težave. Leta 1949 je stres dobil dodatno obrazložitev, ko ga je v medicino uvedel Selye. Pomen stresa je obrazložil na biološki ravni, kot odgovor na dražljaje (škodljive snovi), ki vplivajo na osebno ravnotežje (Božič 2003, str. 17). Po mnenju Teržanove (2002, str. 4) stres izzove prevelik izziv, ki ga ni mogoče doseči. Stres je stranski produkt sodobnega življenja, ki izhaja iz našega prizadevanja za uravnoteženje potreb poklicnega (delovnega) in družinskega življenja, povzemata Ornelas in Kleiner (2003, str. 65).

Evropska fundacija za izboljšanje življenjskih in delovnih razmer (2006, str. 2) opredeljuje stres vezan na delovno mesto kot vzorec odzivov, ki se pojavijo, ko delavci nimajo znanj ali veščin, da bi opravili zahtevano delovno nalogo. Ornelas in Kleiner (2003, str. 64) menita, da je delo glavni dejavnik stresa $v$ zahodni družbi. Vsako delovno mesto nosi posebne zahteve in ljudje se z njimi spopadamo na različne načine. Avtorja ugotavljata, da ljudje v službi in vprašanjih povezanih z delom, porabimo več kot deset ur na dan. Soočati se moramo s pritiski na delovnem mestu, pa tudi z osebnimi odnosi, financami in spremembami, ki so stresne.

Treven (2005, str. 13-14) razlaga, da je stres vzrok za številne psihične in fizične bolezni, ki vodijo v prezgodnjo smrt, nezadovoljstvo in družinske težave. Looker in Gregson (1993, str. 87) menita, da so izostanki od dela zaradi bolezni, posledica stresa. Med drugim izpostavljata tudi stres, ki vodi do slabega zdravja in posledično predčasnih upokojitev, prezgodnjih smrti delavcev ipd. Blatnik, Marinšek in Tušak (2016, str. 3) opozarjajo, da v Sloveniji več kot tri četrtine zaposlenih doživlja stres na delovnem mestu in da so duševne bolezni eden najpogostejših vzrokov za absentizem.

Za odpravljanje stresa na delovnem mestu in v življenjskem okolju, je ključno evidentiranje dejavnikov tveganja na delu ter prepoznavanje osebnih reakcij na stres (Teržan 2002, str. 7). Bilban (2007, str. 32) navaja naslednje dejavnike, ki naj bi vodili v stres na delu: organiziranost dela (preobremenjenost $\mathrm{z}$ delom, redki odmori za počitek, dolgi delovni čas, naporne in rutinske naloge), slog menedžmenta (pomanjkanje udeležbe delavcev pri 
odločanju, slaba komunikacija $\mathrm{v}$ organizaciji, nejasnost vlog in pomanjkanje pravil), medosebni odnosi (pomanjkanje podpore s strani sodelavcev in nadzornikov, nasilne grožnje, nadlegovanje), delovne vloge (nasprotujoča si ali negotova pričakovanja o zaposlitvi, prekomerna delovna odgovornost), kariera (negotovost zaposlitve, pomanjkanje priložnosti za rast ali napredovanje) in okoljski pogoji (nevarne fizične razmere kot so gneča, hrup, onesnaženost zraka ali ergonomske težave).

Pavlič in Markič (2010, str. 18) sta razvrstila stres v naslednjih pet dejavnikov: fizični (nefiziološki položaji, premeščanje bremen, stoja, hoja, ponavljajoči gibi), fizikalni (hrup in vibracije, visoka in nizka temperatura, sevanje, razsvetljava), kemijsko-biološki (dim, prah, plini, kemikalije, tobačni dim, infektivne snovi, iritativne snovi), organizacijski (hitrost dela, časovni pritiski, pomanjkanje odmorov, nočno delo, delo z ljudmi, nevarnost poškodb in zdravstvenih okvar), psihosocialni (fizično nasilje, socialna negotovost, ustrahovanje, poniževanje, nadlegovanje, diskriminacija, spolno nadlegovanje, nespoštovanje znanja in veščin, telesna in zdravstvena hendikepiranost, nedefinirane kompetence, psihološki pritiski, medsebojni odnosi, kriminal, korupcija, razkorak med zahtevami in zmožnostmi).

Dispenza (2018, str. 139) združuje vse naštete oblike stresa in jih klasificira $v$ tri vrste dejavnikov: fizični stres (travme), kemični stres (strupi) in čustveni stres (strah, zaskrbljenost, preobremenjenost, itd.).

Tematika stresa na delovnem mestu ponuja veliko priložnosti za njeno teoretično, raziskovalno in empirično proučevanje $v$ gospodarskih družbah (podjetjih) in javnih zavodih (ustanovah), kar nam je predstavljalo raziskovalni izziv s katerim smo se soočili. Narava in način izvajanja dela $\mathrm{v}$ sodobnem družbenem in gospodarskem okolju je prinesla premik osredinjenosti raziskav na promocijo zdravja in zadovoljstvo z delovnim mestom, uspešnost organizacije, brezposelnost, prezentizem in absentizem ter druge s stresom povezane vsebine, o katerih v preteklosti ni bilo veliko zanimanja. Stopnja stresa in negativne posledice na zdravje, ki jih prinaša za delodajalce, delojemalce in širšo družbo se namreč izjemno stopnjujejo (npr. 62 odstotkov bankrotov v ameriških podjetjih je posledica nezmožnosti plačevanja računov lastnikov za zdravljenje njihovih bolezni) (WHO 2010, str. 9).

Namen članka je bil opraviti sistematični pregled literature na temo vzrokov, dejavnikov in posledic stresa na različnih ravneh organiziranosti menedžerjev v Republiki Sloveniji od leta 2005-2019. Avtorji dosedanjih raziskav v RS so proučevali vzroke, dejavnike in posledice stresa na različnih delovnih mestih $\mathrm{v}$ gospodarskih in negospodarskih dejavnostih ter $\mathrm{v}$ pridobitnih in nepridobitnih organizacijah. Doslej pa še ni bil opravljen sistematičen pregled strokovne literature o prisotnosti stresa na različnih ravneh organiziranosti menedžerjev v RS in zato obstaja vrzel v znanju o resnosti tega pojava. Ne obstajajo celovite informacije o tem kolikšna je stopnja stresa pri spodnjih, srednjih in vršnih menedžerjih $\mathrm{v}$ slovenskih organizacijah, kar nam je predstavljalo raziskovalni izziv s katerim smo se soočili. Pomanjkanje celovitih informacij o stopnji stresa pri spodnjih, srednjih in vršnih menedžerjih 
je identificirana raziskovalna vrzel, ki jo bomo poizkusili $\mathrm{z}$ našo raziskavo vsaj delno zapolniti.

\section{Metoda}

V teoretičnem delu smo uporabili proces sistematičnega pregleda literature, ki je bil opravljen v obdobju marec-maj 2020. Pregledali smo domačo in tujo literaturo s področja stresa na delovnem mestu spodnjih, srednjih in vršnih menedžerjev. Pri pregledu literature, smo iskali aktualne strokovne, znanstvene in raziskovalne članke, ki so bili objavljeni po letu 2005 Pomagali smo si z naslednjimi mednarodnimi in domačimi bibliografskimi bazami:

- Google Učenjak (angl. Google Scholar) iskalnik, iz katerega smo preučili izbrane recenzirane in nerecenzirane prispevke, članke, disertacije, diplomske naloge in izvlečke iz raznih izobraževalnih organizacij. Do njega smo dostopali preko povezave https://scholar.google.com/

- Cobiss.si oz. slovenski knjižnični sistem, v katerem smo imeli dostop do nacionalnih, univerzitetnih in visokošolskih knjižnic, splošnih in specialnih knjižnic. Vzajemna baza podatkov zajema več kot 4.500 .000 bibliografskih zapisov, kjer smo uporabili raziskave monografskih publikacij (doktorskih disertacij, magistrskih nalog, diplomskih nalog in zaključnih projektnih nalog) opravljenih med leti 2005 in 2019. Dostopen nam je bil na povezavi https://www.cobiss.si/.

- SpringerLink baza, ki vsebuje približno 1.900 znanstvenih in strokovnih revij iz področij biomedicinske, naravoslovne in tehnične vede, menedžment in ekonomijo, humanistiko, psihologijo itd. Do baze SpringerLink smo dostopali preko povezave https://link.springer.com/.

- Nekatere podatke smo pridobili neposredno iz spletnih strani:

- Europian Agency for Safety and Health at Work (EU-OSHA) https://osha.europa.eu/en,

- Eurostat https://ec.europa.eu/eurostat/home?

- International Labour Organization (ILO) https://www.ilo.org/global/lang-en/index.htm

- Health and safery executive (HSE) https://www.hse.gov.uk/

- National Institute for Occupational Safety and Healt (NIOSH) https://www.cdc.gov/niosh/index.htm

- The American Institute of Stress https://www.stress.org/

Pregled strokovne literature je bil izveden s pomočjo ključnih besed v slovenskem in angleškem jeziku. Za sortiranje gradiva in teoretičnih izhodišč $\mathrm{v}$ bibliografskih bazah 
podatkov, smo uporabili pojme v angleškem jeziku: workplace, stress, work, low manager, middle manager, top manager in management. Ker nas je zanimalo stanje obravnavane tematike v Republiki Sloveniji, smo uporabili prevedene pojme: delovno mesto, stres, delo, spodnji menedžer, srednji menedžer, vršni menedžer in menedžment. Pojme smo povezovali $\mathrm{z}$ Boolovima operaterjema AND oz. OR v različnih kombinacijah. Za izbor teh ključnih besed smo se odločili zato, ker so odražale osnovno raziskovalno vsebino.

Po prvem pregledu povzetkov, smo izločili literaturo, ki se ni skladala z namenom raziskave. Starost znanstvene literature pri teoretičnih izhodiščih nismo točno omejili, saj nas je zanimalo zgodovinsko in sedanje dogajanje obravnavane tematike. Pri trenutnem stanju empiričnih raziskav o stresu pri spodnjih, srednjih in vršnih menedžerjih v Sloveniji smo se fokusirali na zadnjih petnajst let oz. na strokovni literaturi od leta 2005-2019.

Metoda za analizo dokumentov je bil sistematičen način zmanjševanja virov in kvantitativne analize njihovih značilnosti (Slika 1). Za analizo smo pridobili 476 člankov v polnem besedilu. Dobljene rezultate smo omejili na angleški in slovenski jezik, kar nam je prineslo 438 člankov za analizo.

Nabor člankov smo dodatno selekcionirali na podlagi primernosti naslova in vsebine povzetka ter na ta način pridobili 47 člankov za podrobnejšo analizo.

Članke smo analizirali z namenom, da bi poudarili določene ugotovitve in identificirali razlike ter skladnost med njimi. Iskali smo strokovno literaturo, ki prikazuje stanje stresa na delovnem mestu na splošno in na vseh ravneh organiziranosti menedžmenta. Izločili smo še članke, ki niso vsebovali ključnih podatkov (vpliv stresa na delo, statistični podatki o stresu, zaznavanje stresa na delovnem mestu in odzivi ter stres $\mathrm{v}$ menedžmentu). Izbrani so bili članki, ki so se nanašali na stres na delovnem mestu in aktualne probleme $\mathrm{v}$ zvezi z njim. Izračunali smo aritmetično sredíno ali povprečje oz. poprečje niza podatkov iz ključnih ugotovitev o samooceni menedžerjev na prisotnost stresa na njihovem delovnem mestu $\mathrm{v}$ odstotkih. Sešteli smo vse vrednosti ter jih razdelili na skupno število teh vrednosti oziroma podatkov.

Za končno analizo smo pridobili deset člankov, ki smo jih $\mathrm{v}$ nadaljevanju podrobneje analizirali ter predstavili. 


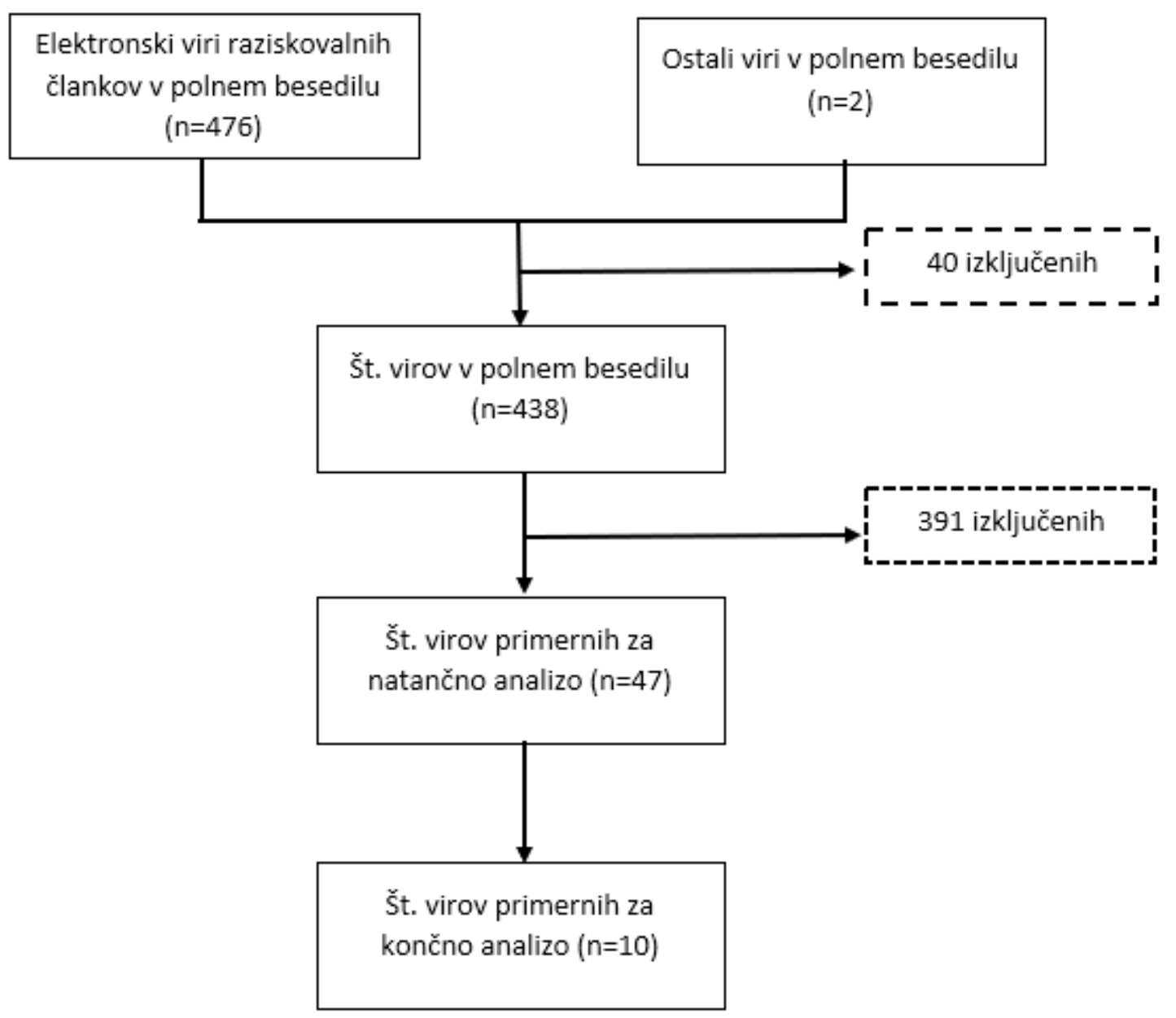

Slika 1. Prizma diagram

\section{Rezultati in razprava}

V tabeli 1. Pregled raziskav so opisani izbrani članki, ki so se nanašali na stres na delovnem mestu spodnjega, srednjega ali vršnega menedžerja in aktualne probleme v zvezi z njim. Članki so vsebovali izide iz konkretne raziskave, ter so bile uporabljene osnovne metodološke zahteve (materiale in vzorec) in temeljne ugotovitve. 
Tabela 1. Pregled raziskav

\begin{tabular}{|c|c|c|}
\hline Avtor, letnica & Metode, vzorec & Ključne ugotovitve \\
\hline $\begin{array}{l}\text { Meško in } \\
\text { drugi } \\
(2008)\end{array}$ & $\begin{array}{l}\text {-85 menedžerjev (ni navedeno katerih) iz } \\
\text { naključno izbranih slovenskih podjetij. } \\
\text {-Za namen raziskave je bil skonstruiran } \\
\text { vprašalnik Stresne obremenitve na } \\
\text { delovnem mestu menedžerja. }\end{array}$ & $\begin{array}{l}27,1 \text { odstotka menedžerjev je ocenilo } \\
\text { njihovo delo kot zelo do izjemno stresno. } \\
61,1 \text { odstotka menedžerjev ocenjuje svoje } \\
\text { delo kot zmerno stresno, } 11,8 \text { odstotka pa } \\
\text { kot nekoliko stresno. }\end{array}$ \\
\hline (2009) & $\begin{array}{l}\text {-53 menedžerjev večjih in manjših } \\
\text { gospodarskih podjetij in javnih služb po } \\
\text { celi Sloveniji (ni navedbe kateri } \\
\text { menedžerji so bili vključeni). } \\
\text {-Za namen raziskave je bil uporabljen } \\
\text { vprašalnik, sestavljen na podlagi } \\
\text { literature. }\end{array}$ & $\begin{array}{l}22,64 \text { odstotka anketiranih menedžerjev } \\
\text { meni, da je njihovo delo tako stresno, da se } \\
\text { dokaj pogosto počutijo izčrpane in ne } \\
\text { zmorejo več opravljati delovnih nalog. } \\
45,27 \text { odstotka anketiranih te občutke } \\
\text { doživlja včasih, } 26,42 \text { odstotka pa zelo } \\
\text { redko. Le } 3,77 \text { odstotka anketiranih je } \\
\text { odgovorilo, da njihovo delo nikoli ni tako } \\
\text { stresno, da bi se počutili izčrpane in } \\
\text { nezmožne opravljati delovnih nalog. }\end{array}$ \\
\hline $\begin{array}{l}\text { Murn } \\
\text { (2009) }\end{array}$ & $\begin{array}{l}\text { - } 85 \text { menedžerjev naključno izbranih } \\
\text { slovenskih podjetij, od tega } 43 \text { žensk in } \\
42 \text { moških. } \\
\text { - Za namen raziskave je bil skonstruiran } \\
\text { anketni vprašalnik Stresne obremenitve } \\
\text { na delovnem mestu menedžerja. }\end{array}$ & $\begin{array}{l}\text { V raziskavi } 61,2 \text { odstotka menedžerjev } \\
\text { ocenjuje svoje delo kot zmerno stresno. } \\
\text { Svoje delo je kot zelo do izjemno stresno } \\
\text { ocenilo } 27,1 \text { odstotka anketiranih, } 11,8 \\
\text { odstotka pa kot nekoliko stresno. }\end{array}$ \\
\hline $\begin{array}{l}\text { Kern } \\
(2010)\end{array}$ & $\begin{array}{l}\text {-30 menedžerk zaposlenih v srednjem } \\
\text { menedžmentu, iz različnih podjetij in } \\
\text { delov Slovenije. } \\
\text {-Za namen raziskave je bil uporabljen } \\
\text { anketni vprašalnik, narejen na podlagi } \\
\text { teoretičnih izhodišč. }\end{array}$ & $\begin{array}{l}26,66 \text { odstotka ženskih menedžerk vedno } \\
\text { občuti stres na delovnem mestu, } 56,67 \\
\text { odstotka anketiranih pri sebi pogosto } \\
\text { prepozna negativni stres, } 10 \text { odstotkov le } \\
\text { včasih in } 6,67 \text { odstotka redko. }\end{array}$ \\
\hline $\begin{array}{l}\text { Kožuh in } \\
\text { Arzenšek } \\
(2011)\end{array}$ & $\begin{array}{l}\text {-58 srednjih menedžerjev, zaposlenih } \mathrm{v} \\
\text { trgovinski dejavnosti v ljubljanski regiji. } \\
\text {-Kot instrument raziskave je bil } \\
\text { uporabljen vprašalnik. }\end{array}$ & $\begin{array}{l}48,3 \text { odstotka anketiranih srednjih } \\
\text { menedžerjev ocenjuje svoje delo kot } \\
\text { srednje stresno, } 25,9 \text { odstotka kot nekoliko } \\
\text { stresno in } 20,7 \text { odstotka kot večinoma } \\
\text { stresno. Povsem ne stresno doživljata svoj } \\
\text { položaj le dva srednja menedžerja ( } 3,4 \\
\text { odstotka), zelo stresno pa le en anketiranec. }\end{array}$ \\
\hline
\end{tabular}


»nadaljevanje«

Premrl $\quad-67$ menedžerjev (ni navedeno katerih), od tega je 36 žensk in 31 moških.

-Za namen raziskave stresa menedžerjev

v Sloveniji je uporabila anketni vprašalnik v obliki spletne ankete.
43 odstotkov vseh anketirancev meni, da je delo včasih tako stresno, da se počutijo izčrpane in ne zmorejo več opravljati delovnih nalog. 39 odstotkov oseb je odgovorilo, da doživljajo ta občutek zelo redko, 15 odstotkov dokaj pogosto in 3 odstotke zelo pogosto.

41,1 odstotka anketiranih doživlja svoje delo kot zmerno stresno. Temu sledijo tisti, ki delo občutijo kot nekoliko stresno (29,7 odstotka) in zelo stresno (21,6 odstotka). Odstotka anketiranih, ki svoje delo ocenjujejo kot povsem ne stresno ali izjemno stresno, sta enaka in znašata 1,6 odstotka. vprašalnik iz dveh različnih vprašalnikov: vprašalnik spoprijemanja $\mathrm{s}$ stresom CPI in vprašalnik stresnih obremenitev in simptomov stresa pri menedžerjih.

Breznik $\quad-95$ menedžerjev naključno izbranih slovenskih podjetij. Od tega 69 odstotkov moških in 31 odstotkov žensk.

-Za pridobivanje odgovorov je bil strukturiran vprašalnik.
Največ menedžerjev, 42,1 odstotka svoje delo ocenjuje kot zmerno stresno, 27,4 odstotka jih meni, da je njihovo delo zelo stresno in 22,1 odstotka da je njihovo delo nekoliko stresno. Kot izjemno stresno svoje delo ocenjuje 5,3 odstotka in povsem ne stresno 3,1 odstotka.

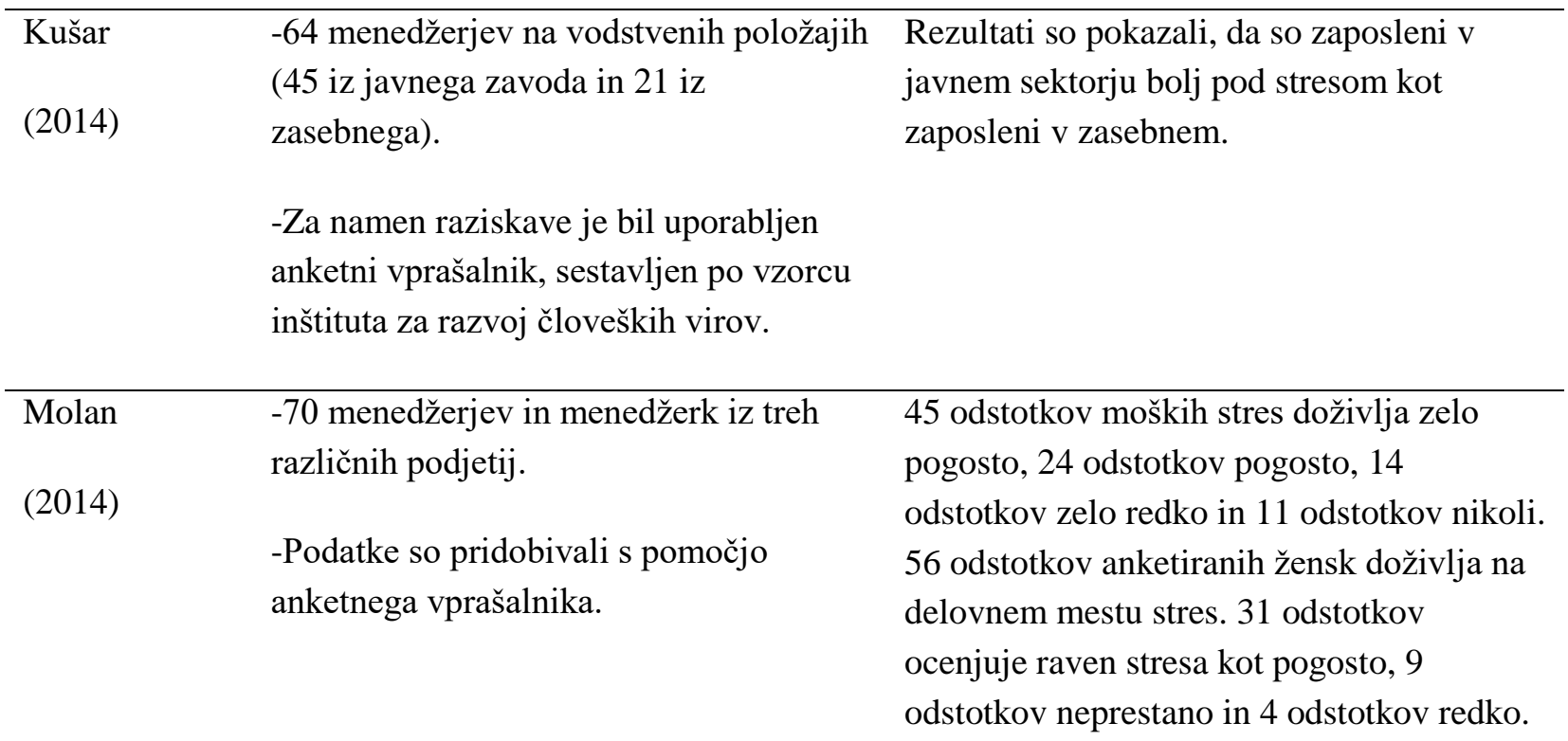


Po pregledu domače in tuje strokovne literature smo ugotovili, da je problematika stresa na delovnem mestu menedžerjev vedno večji problem in da obsega širok nabor in možnosti za teoretično in empirično proučevanje.

V doktorskih dizertacijah je stres raziskovalno 145 avtorjev a nihče od njih doslej še ni analiziral stresa pri managerjih. V magistrskih nalogah je stres raziskovalo 531 avtorjev od tega so se štirje avtorji (David 2009; Ozebek 2011; Kušar 2014; Molan 2014) ukvarjali s prisotnostjo stresa na delovnem mestu menedžerjev. Največ raziskav na tematiko stresa je bilo v diplomskih nalogah in zaključnih strokovnih nalogah visokih šol, 2.393, od katerih smo za nadaljnjo analizo ocenili kot primerne štiri diplomske naloge (Murn 2009; Kern 2010; Premrl 2011; Breznik 2012). Ostali avtorji, Meško in drugi (2008) so izvedli raziskavo v kateri so želeli ugotoviti stopnjo stresa, ki ga na delu doživljajo menedžerji. Kožuh in Arzenšek (2011) sta v raziskavi ugotavljali razlike med stresorji, vezanimi na odnose znotraj organizacije in stresorji, vezanimi na vsebino dela pri srednjem menedžmentu.

Na podlagi pregleda literature s področja stresa na delovnem mestu lahko povzamemo, da je tematika vedno bolj aktualna in odpira možnosti za preučevanje tako domačih kot tujih raziskovalcev. V Sloveniji ni bilo opravljenih veliko raziskav na področju stresa, vezanih na specifična delovna mesta managerjev (vršnih, srednjih ali nižjih). V analiziranem 15-letnem obdobju od leta 2005-2019 je bilo v RS skupaj anketiranih zgolj 718 menedžerjev. Od teh je bilo 64 menedžerjev anketiranih kot osebe na vodstvenih položajih (Kušar 2014), 198 kot srednji in nižji. Za ostalih 456 anketiranih menedžerjev ni podatkov o tem na katerem nivoju organiziranosti oz. delovnem mestu so bili zaposlenih. Za pridobivanje podatkov in informacij so avtorji uporabili vprašalnike, ki so jih večinoma sami sestavili in jih niso predhodno testirali ali preverjali njihovo veljavnost. Zgolj v eni raziskavi (Ozebek 2011) je bil uporabljen splošno uveljavljen vprašalnik CPI, kljub temu da je na voljo množica testiranih in uveljavljenih. Raziskovalci so uporabljali zelo različne lestvice za določanje ravni dojemanja stresa med slovenskimi vršnimi, srednjimi in spodnjimi menedžerji, zato je skupno oceno zelo težko podati. Prevladujoča je bila uporaba štiri stopenjske ravni dojemanja stresa (David 2009; Kern 2010; Kožuh \& Arzenšek 2011; Premrl 2011; Ozebek 2011; in Molan 2014), ena pet-stopenjska (Breznik 2012) in dve tri-stopenjski (Meško in drugi 2008, Murn 2009). V celoti so v povprečju anketirani menedžerji v Sloveniji raven dojemanja stresa na njihovem delovnem mestu v preteklih petnajstih letih ocenili v povprečju kot zelo stresno v 39,6 odstotka, kot srednje stresno v 37, 3 odstotka, malo stresno v 15,2 odstotka in ne stresno v 7,9 odstotka. Pomembna je tudi ugotovitev, da je od zadnje raziskave o dojemanju stresa na delovnem mestu slovenskega vršnega, srednjega ali spodnjega menedžerja minilo šest let (Molan 2014), kar je v nasprotju s prevladujočimi trendi na področju proučevane tematike in zaradi tega ji je potrebno nameniti bistveno več pozornosti. Sklenemo lahko, da je raziskovanje doživljanja stresa med slovenskimi vršnimi, srednjim in spodnjimi menedžerji zelo zapostavljen vidik, ki bi mu morala menedžerska znanost in stroka bistveno bolj prisluhniti, še posebej glede na najbolj stresna delovna mesta (Kensing 2019, str. 1) in evidentirane posledice (WHO 2010, str. 9). 


\section{Zaključek}

Stres je postal neizogiben spremljevalec našega delovnega in življenjskega okolja in $\mathrm{z}$ razvojem družbe se nenehno povečuje ter s seboj prinaša fizične, fizikalne, kemijskobiološke, organizacijske in psihosocialne težave (Pavlič in Markič 2010, str. 18), ki vodijo v poškodbe ter zdravstvene okvare. Kakovost dela in kakovost življenja večine prebivalcev sveta v zadnjih treh desetletjih pada (Reich 2009, str. 4), zato je večina zaposlenih nezadovoljnih z delom, ki ga opravljajo (Pfeffer 2015, str. 12). Posledica tega je, da zaradi poškodb in zdravstvenih okvar $\mathrm{v}$ podjetjih ali drugih ustanovah letno umre 2,78 milijona (so)delavcev (WHO 2018, str. 7), kar je v veliki meri mogoče preprečiti. Med najbolj stresna delovna mesta, pr. poleg vojaških, gasilskih, letalskih, policijskih ipd., sodi tudi delovno mesto vršnega menedžerja v gospodarski družbi (Kensing 2019, str. 1). Ugotovili smo, da doslej še ni bil opravljen sistematičen pregled strokovne literature o prisotnosti stresa na različnih ravneh organiziranosti menedžerjev v RS in zato obstaja vrzel v znanju o resnosti tega pojava. Namen naše raziskave je bil opraviti sistematični pregled strokovne literature na temo vzrokov, dejavnikov in posledic stresa na različnih ravneh organiziranosti menedžerjev v Republiki Sloveniji od leta 2005-2019.

Ugotovili smo, da je bilo v preteklih petnajstih letih v RS na različnih ravneh organiziranosti menedžerjev opravljenih 12 empiričnih raziskav, do dveh (Rolih 2008; Lukan 2009) nismo imeli prostega dostopa, ker niso javno dosegljive. Vanje je vključenih 64 vršnih in 198 kot srednjih in nižjih menedžerjev, za preostalih 456 ni bilo podatkov. V preteklih petnajstih letih je bilo opravljenih 145 doktorskih raziskav s področja stresa na različnih delovnih mestih, a nobene o zaznavanju stresa med slovenskimi vršnimi, srednjim ali spodnjimi menedžerji. V magistrskih nalogah je bilo opravljenih 531 raziskav s področja stresa na različnih delovnih mestih, od tega štiri (Rolih, 2008; David, 2009; Lukan, 2009 in Ozebek, 2011) o zaznavanju stresa med slovenskimi vršnimi, srednjim ali spodnjimi menedžerji. Največ raziskav s področja stresa in na različnih delovnih mestih je bilo v diplomskih nalogah ali zaključnih projektnih delih pri katerih smo evidentirali 2.393 zadetkov. O zaznavanju stresa med slovenskimi vršnimi, srednjimi ali spodnjimi menedžerji je bilo razdeljenih 718 anket. Za pridobivanje podatkov so raziskovalci uporabljali različne vprašalnike, ki so jih sami formirali ali povzeli po drugih avtorjih, prevladovala je 4-stopenjska lestvica. Kot zelo do izjemno stresno je v povprečju njihovo delo ocenilo 39,6 odstotka, kot srednje stresno 37,3 odstotka, malo stresno 15,2 odstotka in ne stresno 7,9 odstotka anketiranih slovenskih menedžerjev.

Prispevek rezultatov iz naše raziskave k menedžerski znanosti in stroki je tako teoretičen kot empiričen, pa tudi praktičen. V teoretičnem delu smo opravili pregled strokovne literature na tematiko stresa, vzrokov in posledic stresa ter odpravljanje stresa. Podrobneje smo predstavili dejavnike, ki naj bi vodili $\mathrm{v}$ stres na delovnem mestu ter evidentirali raziskovalno vrzel. Ugotovili smo, da ne obstajajo informacije o tem kolikšna je prevladujoča stopnja zaznavanja stresa pri vršnih, srednjih in spodnjih menedžerjih $\mathrm{v}$ slovenskih organizacijah. $\mathrm{S}$ sistematičnim pregledom strokovne literature $\mathrm{s}$ področja stresa na delovnem mestu vršnih, 
srednjih in spodnjih menedžerjev s slovenskih organizacijah, prinašamo nova znanja, ki jih doslej še ni bilo in predstavljajo novost na področju menedžerske znanosti. Z izvirnimi ugotovitvami iz opravljenega pregleda dosedanjih raziskav smo ocenili in razvrstili stopnjo zaznanega stresa med slovenskimi menedžerji. Pripravili smo priporočila za nadaljnje raziskovanje o dojemanju stresa med slovenskimi menedžerji. Priporočila za menedžersko prakso naj bi imela praktične implikacije tudi za vse tiste, ki se bodo ukvarjali z načrtovanjem, organiziranjem, vodenjem in kontroliranjem razvojno-raziskovalnih procesov na področju stresa v slovenskih gospodarskih družbah in drugih ustanovah.

Pri načrtovanju in izvedbi sistematičnega pregleda stresa med slovenskimi vršnimi, srednjimi in spodnjimi menedžerji smo se soočali z različnimi predpostavkami. Predpostavljali smo, da je bila raziskovanju dojemanja stresa med slovenskimi vršnim, srednjimi in spodnjimi menedžerji, namenjena relativna velika pozornosti teoretikov, raziskovalcev in praktikov. Predpostavljali smo, da je razvrščanje dojemanja stresa menedžerjev $\mathrm{v}$ tri predhodno definirane stopnje (visoko, zmerno in majhno) tega celovito zajamemo in je ustrezen kazalnik omenjenega pojava. Predpostavljali smo tudi, da bo v opravljenih empiričnih raziskavah na voljo dovolj konkretnih informacij, na podlagi katerih bomo lahko z metodo sinteze povzeli najbolj bistvene značilnosti populacije, vzorca, metodologije ter vprašalnika. Pri načrtovanju in izvedbi raziskave smo identificirali različne omejitve. $\mathrm{V}$ okviru preučevanih raziskav smo se omejili zgolj na javno dostopne elektronske vire, ker $\mathrm{v}$ času $\mathrm{v}$ katerem je bila raziskava izvedena, osebno ni bilo mogoče dostopati do literature. Pri izbiri raziskav smo se omejili zgolj na slovenske raziskave $\mathrm{v}$ preteklih petnajstih letih. Rezultatov iz sistematičnega pregleda strokovne literature o stresu menedžerjev ne bo možno posplošiti na vse nivoje organiziranosti, ker v izvedenih anketah ni bilo dovolj informacij, ki bi nam to omogočale.

Glede na izide iz naše analize o ravni dojemanja stresa med slovenskimi vršnimi, srednjimi in spodnjimi menedžerji v Republiki Sloveniji, je mogoče podati tudi možnosti za nadaljnje raziskovanje. $V$ prihodnjih raziskavah bi bilo smiselno razširiti pregled strokovne literature na daljše obdobje oz. do takrat, ko je bila opravljena prva tovrstna raziskava pri menedžerjih. Z namenom pridobitve boljšega vpogleda $v$ razsežnosti dojemanja stresa pri menedžerjih bi bilo zato vsako nadaljnjo raziskavo smiselno zasnovati širše in pregledati strokovno literaturo $\mathrm{v}$ tujih relevantnih javno dostopnih bazah. Raziskovanje ravni dojemanja stresa bi bilo koristno opraviti tudi po demografskih značilnostih organizacije kot npr. velikosti, življenjskega ciklusa, dejavnosti, pridobitnih, javnih ipd. ali pa npr. med vršnimi, srednjimi in spodnjimi menedžerji v zdravstvu, trgovini, policiji, medijih, vojski, gasilstvu ipd. 


\section{Reference}

1. Bilban, M. (2007). Kako razpoznati stres v delovnem okolju. Delo in varnost, letnik 52, številka 1, str. 30-35. Pridobljeno 16. 1. $2020 \mathrm{iz} \mathrm{https://www.dlib.si/stream/URN:NBN:SI:DOC-}$ ZFZGQ5EG/dc4bbf5c-31d7-4147-b965-27c16eb1ef6c/PDF

2. Blatnik, P., Marinšek, M., \& Tušak, M. (2016). Stres, absentizem in ekonomski vidiki telesne neaktivnosti. V P. Blatnik, M. Marinšek, \& M. Tušak, Psihološki, ekonomski in pravni vidiki promocije zdravja na delovnem mestu (str. 46-66). Ljubljana: Univerza v Ljubljani, Fakulteta za šport.

3. Božič, M. (2003). Stres pri delu: priročnik za odpravljanje in prepoznavanje stresa pri delu poslovnih sekretarjev. Ljubljana: GV Izobraževanje.

4. Breznik, M. (2012). Življenjski slog in stres pri slovenskih managerjih (Diplomsko delo). Apače. Pridobljeno iz https://core.ac.uk/download/pdf/67567439.pdf

5. David, T. (2009). Stres managerjev v Sloveniji (Magistrsko delo). Ljubljana: Univerza v Ljubljani, Ekonomska fakulteta. Pridobljeno iz https://plus.cobiss.si/opac7/bib/18412518

6. Dispenza, J. (2018). Placebo ste vi: vaš um je pomemben. Brežice: Primus.

7. EU-OSHA. (2014). Calculating the cost of work-related stress and psychosocial risks. Luxembourg: Publications Office of the European Union. doi:10.2802/20493

8. Eurofund. (2010). European Foundation for the Improvement of Living and Working Conditions. Pridobljeno iz Work related stress: https://www.eurofound.europa.eu/sites/default/files/ef_files/docs/ewco/tn1004059s/tn1004059s.pd $\mathrm{f}$

9. Eurostat. (2017). Eurostat. Pridobljeno 23. $12020 \mathrm{iz} \mathrm{https://ec.europa.eu/eurostat/statistics-}$ explained/index.php?title=Self-reported_work-related_health_problems_and_risk_factors__key_statistics

10. Eurostat. (11 2019). Eurostat. Pridobljeno 23. $12020 \mathrm{iz} \mathrm{https://ec.europa.eu/eurostat/statistics-}$ explained/index.php?title=Accidents_at_work__statistics_on_causes_and_circumstances\#Workstation_accidents

11. Health and Safety Executive. (31. oktober 2019). What are the Management Standards? Pridobljeno iz https://www.hse.gov.uk/stress/standards/

12. ILO. (2016). WORKPLACE STRESS: A collective challenge. Geneva: ILO Publications .

13. Kern, V. (2010). Managerke in obvladovanje stresa v management (Diplomsko delo). Koper. Univerza na Primorskem, Fakulteta za management. Pridobljeno iz https://repozitorij.upr.si//zpisGradiva.php?id=4048

14. Kensing, K. (2019). Three-Quarters of Workers Are Stressed, Says New CareerCast Survey. Pridobljeno iz: https://www.prnewswire.com/news-releases/three-quarters-of-workers-arestressed-says-new-careercast-survey-300807080.html

15. Kožuh, P., \& Arzenšek, A. (2011). Medosebni odnosi in vsebina dela kot dejavnika stresa pri srednjem managementu. str. 177-189. Pridobljeno iz https://repozitorij.upr.si/IzpisGradiva.php?lang=slv\&id=4194

16. Kušar, J. (2014). Model preprečevanja managerskega izgorevanja na delovnem mestu (Magistrsko delo). Univerza v Mariboru, Fakulteta za organizacijske vede. Pridobljeno iz https://dk.um.si/Dokument.php?id=63885

17. Looker, T., \& Gregson, O. (1993). Obvladajmo stres. Ljubljana: Cankarjeva založba.

18. Meško, M., Meško, Š. Z., Podbregar, Z., \& Karpljuk, D. (2008). Stresne obremenitve na delovnem mestu managerja. Organizacija: Journal of Management, Informatics and Human Resources, letnik 41, številka 2, str.89-96. Pridobljeno iz http://organizacija.fov.unimb.si/index.php/organizacija/article/view/234/468

19. Molan, A. (2014). Stres v managementu - Razlike med spoloma (Magistrsko delo). Maribor. Pridobljeno iz https://plus.si.cobiss.net/opac7/bib/11912988

20. Murn, A. (2009). Športna dejavnost in stres pri managerjih v slovenskih podjetjih (Diplomsko delo). Ljubljana. Pridobljeno iz https://www.fsp.unilj.si/COBISS/Diplome/Diploma22045280MurnAndrej.pdf

21. Ornelas, S., \& Kleiner, B. H. (2003). New Developments in Managing Job Related Stress. Equal Opportunities International, letnik 22, številka 5, str. 64-70. Pridobljeno iz 
https://www.emerald.com/insight/content/doi/10.1108/02610150310787504/full/pdf?title=newdevelopments-in-managing-job-related-stress

22. Ozebek, S. (2011). Obvladovanje stresa in absentizem pri managerjih: študija primera (Magistrsko delo). Koper. Univerza na Primorskem, Fakulteta za management. Pridobljeno iz https://repozitorij.upr.si/IzpisGradiva.php?id=2322\&lang=eng\&print=

23. Pavlič, M, \& Markič, M. (2010). Planiranje varnosti in zdravja pri delu iz vidika razvoja stroke. V: Taradi, J. (ur.). Menadžment i sigurnost: M\&S 2010: tema konferencije: Planiranje i sigurnost: programski ciklus: Osnovne funkcije menadžmenta i sigurnost. Čakovec: Hrvatsko društvo inženjera sigurnosti: Visoka škola za sigurnost. 2010, str. 11-20.

24. Pfeffer, J. (2015). Leadership BS: Fixing workplaces and careers one truth at a time. New York: Harper Collins Publishers.

25. Premrl, N. (2011). Stres managerjev v Sloveniji: razlike med spoloma. Zakljčna strokovna naloga visoke poslovne šole. Ljubljana. Univerza v Ljubljani, Ekonomska fakulteta. Pridobljeno iz https://plus.cobiss.si/opac7/bib/20326886

26. Reich, R. (2009). The spirit level. Why Greater Equality makes Societies Stronger. New York: Bloomsbury Press.

27. Slovar slovenskega knjižnega jezika. (2000). Ljubljana: Založna ZRC. Pridobljeno iz https://fran.si/208/sinonimni-slovar/4394386/stres?View=1\&Query=stres

28. Teržan, M. (2002). Dobro se počutim, delo mi je v veselje: preprečujmo stres na delovnem mestu. Ljubljana: Ministrstvo za delo, družino in socialne zadeve, Urad RS za varnost in zdravje pri delu.

29. The American Heritage. (2020). The American Heritage ${ }^{\circledR}$ Dictionary of the English Language (5th izd.). Houghton Mifflin Harcourt Publishing Company. Pridobljeno iz https://ahdictionary.com/word/search.html?q=stress

30. The American Institute of Stress. (2020). The American Institute of Stress. Pridobljeno iz https://www.stress.org/workplace-stress

31. Treven, S. (2005). Premagovanje stresa. Ljubljana: ZVD.

32. WHO. (2010). The world health report: health systems financing: the path to universal coverage. WHO Press, World Health Organization. Geneva: Switzerland.

33. WHO. (2018). World Health Statistics 2018. Monitoring Health for the SDGs, sustainable development goals. Geneva: Switzerland.

Anja Puntar je maturirala na Gimnaziji Brežice in je študentka univerzitetnega dodiplomskega študijskega programa Management na Fakulteti za management Univerze na Primorskem. Izkušnje na področju menedžmenta in podjetništva pridobiva v družinskem podjetju.

$* * *$

Mirko Markič je doktoriral na Fakulteti za organizacijske vede Univerze v Mariboru s področja organizacijskih ved na temo inoviranja. Po dvanajstih letih delovanja v gospodarstvu se je zaposlil na Fakulteti za menedžment Univerze na Primorskem. Je redni profesor za področje menedžmenta in znanstveni svetnik ter vodja ali član 17 raziskovalnih projektov in projektov z gospodarstvom. Njegova bibliografija obsega več kot 630 enot s področja upravnih in organizacijskih ved ter javnega zdravstva (varstvo pri delu). 


\section{Abstract: \\ Stress in the Workplace of Slovenian Managers}

Research Question (RQ): What is the level of perceived stress among Slovenian top, middle and lower managers in the Republic of Slovenia?

Purpose: The purpose of the article was to undertake a systematic review of scientific literature on the causes, factors and consequences of stress at different levels of manager's organisation in the Republic of Slovenia in the period 2005-2019.

Method: The method for document analysis was a systematic manner of reducing resources and a quantitative analysis of their characteristics (using the Prisma flow diagram).

Results: $27,1 \%$ of respondent managers assessed their work as highly or extremely stressful, 61,1 $\%$ as moderately stressful and $11,8 \%$ as somewhat or less stressful.

Society: The research addresses the perception of stress among managers as opportunities for finding potential resolutions to eliminate or limit the factors that have an effect on it. These factors have a negative effect both on the performance of the company or another institution, on the health and social system as well as on the sustainable development of society.

Originality: Through a systematic review of studies performed on perceived stress among Slovenian top, middle and lower managers we arrived at new findings that have not yet been identified in previous studies.

Limitations / further research: The outcomes from the research on the level of perceived stress among Slovenian top, middle and lower managers cannot be generalised to the entire population of managers and they also cannot be generalised to standard activities and the size of a company. We have made some proposals for further research of stress among Slovenian managers.

Keywords: workplace, management, managers, research, Slovenia, stress.

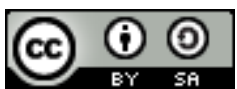

Creative Commons License

This work is licensed under a Creative Commons Attribution-ShareAlike 4.0 International License. 